\title{
Pengaruh Komisaris Independen, Komite Audit Dan Kepemilikan Institusional Terhadap Opini Audit Asumsi Going Concern
}

\author{
Moh. Gusti Ravyanda, Endang Dwi Wahyuni, \\ dan Siti Zubaidah \\ Program Studi Akuntansi Fakultas Ekonomi dan Bisnis \\ Universitas Muhammadiyah Malang \\ Jl. Raya Tlogomas No.246 Malang
}

\begin{abstract}
This research aims to test and give empirical proofs of the influence of the existence of independent commissioner, audit committee, and institutional ownership towards audit opinion. This research used logistic regression analysis. The result of this research shows that independent commissioner, audit committee, and the composition of institutional ownership did not give influences to audit opinion.
\end{abstract}

Keywords: independent commissioner, audit committee, institutional ownership, audit going concern.

\section{PENDAHULUAN}

Sejak krisis keuangan yang terjadi pada akhir tahun 2008 melanda kondisi ekonomi dunia, memberikan pengaruh terhadap kelangsungan hidup ekonomi yang ada di Indonesia. Kondisi ekonomi ini tentunya mempengaruhi aktivitas kelangsungan hidup setiap perusahaan yang ada Indonesia. Kondisi ekonomi akibat krisis ini menuntut perusahaan agar dapat bertahan dan mampu melanjutkan kelangsungan hidup selanjutnya di masa depan (going concern). Untuk mempertahakan dan meningkatkan keberlangsungan hidup perusahaan, tentunya perusahaan harus melaksanakan suatu strategi yang tepat agar keberlangsungan hidup dapat dipertahankan.

Kelangsungan hidup suatu entitas (going concern) selalu dihubungkan dengan kemampuan manajemen dalam mengelola perusahaan, mempertahankan kegiatan usahanya dalam jangka waktu panjang, dan tidak akan menutup usahanya dalam jangka waktu pendek (Dewi, 2011). Asumsi going concern adalah salah satu asumsi yang dipakai dalam menyusun laporan keuangan suatu entitas ekonomi. Asumsi ini mengharuskan entitas ekonomi secara operasional dan keuangan memiliki kemampuan mempertahankan kelangsungan hidupnya atau going concern. Pada kondisi tertentu ada kalanya asumsi going concern tidak dapat dipertahankan atau tidak, karena suatu entitas ekonomi tidak lagi dapat mempertahankan aktivitas ekonominya. Kondisi ini bisa diakibatkan oleh adanya kegagalan bisnis yang disebabkan oleh banyak hal (Purba,2009).

Sari (2012) menyatakan auditor yang independen akan memberikan opini sesuai dengan kondisi perusahaan sebenarnya. Jika dalam proses identifikasi informasi mengenai kondisi perusahaan auditor tidak menemukan adanya kesangsian besar terhadap kemampuan entitas untuk mempertahankan kelangsungan hidupnya, maka auditor akan memberikan opini audit non going concern dan opini audit going concern akan diberikan kepada perusahaan yang oleh audi-

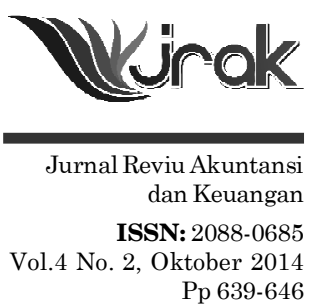




\section{Pengaruh Komisaris Independen...}

tor diragukan kemampuannya dalam menjaga kelangsungan usaha perusahaan. Priyetno (2014) menyatakan bahwa pemberian opini audit going concern merupakan hal yang tidak diharapkan oleh sebuah perusahaan karena dengan pemberian opini audit going concern sebuah perusahaan dapat mengalami penurunan investor, saham, kreditor dan berkurangnya kepercayaan pemegang kepentingan lainnya.

Adi (2011) menyatakan bahwa masalah going concern yang terjadi dapat dicegah dan diatasi dengan adanya suatu aturan untuk mengelola dan mengawasi perusahaan yaitu tata kelola perusahaan yang baik (good corporate governance). Ini dikarenakan salah satu manfaat good corporate governance adalah menjaga going concern perusahaan. Menurut Yustiavandana dan Indra (2006), bagi perusahaan yang berdomisili di negara-negara berkembang, implementasi prinsip good corporate governance dapat memberikan kontribusi untuk memulihkan kepercayaan para kreditor terhadap kinerja suatu perusahaan yang telah dilanda krisis, misalnya Indonesia.

Adapun elemen-elemen good corporate governance dalam penelitian ini meliputi komisaris independen, komite audit dan kepemilikan institusional. Menurut Forum for Corporate Governance in Indonesia (2000) dalam Chandra (2013), bahwa komisaris independen merupakan prinsip corporate governance yang tidak kalah penting dimana mampu menempatkan keadilan (fairness) sebagai prinsip utama dalam memperhatikan pihak-pihak yang mungkin sering terabaikan, misalnya pemegang saham minoritas dan para stakeholder yang lainnya. Selain itu, tugas dewan komisaris untuk mencegah munculnya masalah going concern meliputi: memonitor penggunaan modal perusahaan, investasi dan penjualan aset, memonitor dan mengatasi masalah benturan kepentingan pada tingkat manajemen, anggota dewan komisaris, termasuk penyalahgunaan aset perusahaan dan manipulasi transaksi perusahaan.

Komite audit adalah suatu komite yang beranggotakan satu atau lebih anggota dewan komisaris. Anggota komite dapat berasal dari kalangan luar dengan berbagai keahlian, pengalaman dan kualitas lainnya yang dibutuhkan guna mencapai tujuan komite audit. Komite audit dituntut untuk dapat bertindak secara independen. Independensi komite audit tidak dapat dipisahkan moralitas yang melandaskan integritasnya. Hal ini perlu disadari karena komite audit merupakan pihak yang menjembatani antara eksternal auditor dan perusahaan yang juga sekaligus menjembatani antara fungsi pengawasan dewan komisaris dengan internal auditor (Yustiavandana dan Indra, 2006).

Menurut Rahmawati (2010) kepemilikan institusional merupakan saham perusahaan yang dimiliki oleh institusi atau lembaga (perusahaan asuransi, bank, perusahaan investasi dan kepemilikan institusi lain). Sutedi (2011) menyatakan bahwa salah satu cara yang efektif mempengaruhi perusahaan terbuka adanya institusional investors. Institusional investors biasanya dana pensiun dan asuransi yang bertujuan memaksimalkan investasi mereka ada perusahaan yang menerapkan good corporate governance (GCG). Menurut Schleifer dan Vishny (1986) dalam Wardhani (2007) bahwa tingginya kepemilikan oleh investor institusional akan mendorong aktivitas monitoring karena besarnya kekuatan voting mereka yang akan mempengaruhi kebijakan manajamen.

Penelitian mengenai faktor-faktor yang memengaruhi terjadinya opini $g^{-}$ ing concern telah banyak dilakukan sebelumnya, namun terdapat perbedaan pada riset-riset terdahulu. Hasil penelitian Hartas (2011), Adi (2011) dan Adjani (2013) tentang pengaruh komisaris independen terhadap opini audit going concern yang menyatakan bahwa komisaris independen tidak berpengaruh pada opini audit going concern, sedangkan penelitian Setiawan (2011) komisaris independen berpengaruh negatif dan signifikan terhadap penerimaan opini audit goingconcern. Hasil penelitian Ndoen (2011) menyatakan bahwa komisaris independen berpengaruh positif dan signifikan terhadap penerimaan opini going concern. Hasil 
penelitian Adi (2011), Setiawan (2011) tentang pengaruh komite audit terhadap opini audit asumsi going concern menyatakan bahwa komite audit tidak berpengaruh terhadap opini audit going concern. Hasil penelitian selanjutnya Hartas (2011), Ndoen (2011) menyatakan bahwa kepemilikan konstitusional berpengaruh negatif dan signifikan terhadap penerimaan opini going concern serta hasil penelitian yang dilakukan Irfana (2012) menyatakan kepemilikan institusional berpengaruh terhadap opini audit going concern. Berbeda dengan hasil penelitian Adi (2011), Adjani (2013) bahwa kepemilikan institusional tidak berpengaruh terhadap penerimaan opini audit going concern.

Dari beberapa penelitian, masih ditemukannya perbedaan terhadap hasil penelitian. Oleh karena itu penelitian ini dimaksudkan untuk mengkaji dan menguji kembali pengaruh komisaris independen, komite audit dan kepemilikan institusional terhadap opini going concern studi empiris pada perusahaan yang terdaftar di Bursa Efek Indonesia.

Berdasarkan pernyataan diatas dalam penulisan karya akhir ini, peneliti tertarik mengangkat penulisan ini dengan judul "Pengaruh Komisaris Independen, Komite Audit Dan Kepemilikan Institusional Terhadap Opini Audit Asumsi Going Concern (Studi Empiris pada Perusahaan yang Terdaftar di Bursa Efek Indonesia)". Tujuan dalam penelitian ini adalah menguji dan memberikan bukti empiris pengaruh keberadaan komisaris independen, komite audit dan kepemilikan institusional terhadap opini audit asumsi going concern.

Berdasarkan penjelasan yang dipaparkan disusun hipotesis berikut:

$\mathrm{H}_{1}$ : Komisaris independen berpengaruh terhadap opini audit asumsi going concern.

$\mathrm{H}_{2}$ : Komite audit berpengaruh terhadap opini audit asumsi going concern.

$\mathrm{H}_{3}$ : Kepemilikan institusional berpengaruh terhadap opini audit asumsi going concern.

\section{METODE}

Populasi dalam penelitian ini adalah semua perusahaan yang terdaftar (listing) di Bursa Efek Indonesia (BEI) tahun 2010 - 2012. Sampel yang digunakan dalam penelitian ini adalah metode purposive sampling dengan kriteria perusahaan yang sudah terdaftar di Bursa Efek Indonesia selama periode penelitian 20102012, perusahaan yang terdaftar di BEI yang mengalami laba bersih negatif setelah pajak (kerugian/rugi bersih) sekurangnya dua periode selama periode penelitian 2010-2012, data lengkap dan tersedia selama periode penelitian 2010 sampai 2012, dikarenakan masih ada beberapa perusahaan yang belum menerbitkan laporan keuangan dan laporan tahunan untuk tahun 2010-2012. Jenis data dalam penelitian ini menggunakan data sekunder. Sumber data yang diperoleh berasal situs BEI dari www.idx.co.id.

Teknik pengumpulan data dalam penelitian ini menggunakan metode dokumentasi dengan cara mengumpul, mencatat, dan mengkaji data sekunder dalam laporan keuangan auditan (audited) dan laporan tahunan perusahaan periode pengamatan 2010-2012 yang disediakan secara resmi oleh Bursa Efek Indonesia (www. idx.co.id). Pengujian hipotesis pada penelitian ini menggunakan analisis multivariat pada program SPSS yang menggunakan analisis regresi logistik (logistic regression) karena variabel dependennya diukur secara nominal dan variabel independennya merupakan kombinasi antar metrik dan non metrik (nominal). Teknik analisis ini tidak memerlukan lagi uji normalitas data pada variabel bebasnya. 


\section{Pengaruh \\ Komisaris \\ Independen...}

Tabel 1

Hosmer and Lemeshow Test

reme

HASIL DAN PEMBAHSAN

\begin{tabular}{cccc}
\hline Step & Chi-square & Df & Sig. \\
\hline 1 & 5.157 & 8 & .074 \\
\hline Sumber: Output SPSS 16.0 & &
\end{tabular}

Output tabel 1 menunjukkan hasil pengujian Hosmer and Lemeshow. Probabilitas signifikasi menunjukkan angka 0,074 yang berarti bahwa nilai signifikansi yang diperoleh ini lebih besar dari pada $0,05(7,41 \%>5 \%)$. Hal ini berarti model regresi layak untuk digunakan dalam analisis selanjutnya, karena tidak ada perbedaan yang nyata antara klasifikasi yang diprediksi dengan klasifikasi yang diamati, atau dapat dikatakan bahwa model mampu memprediksi nilai observasinya.

\begin{tabular}{cccc}
\hline Step & -2 Log likelihood & $\begin{array}{c}\text { Cox \& Snell } \\
\text { R Square }\end{array}$ & $\begin{array}{c}\text { Nagelkerke R } \\
\text { Square }\end{array}$ \\
\hline 1 & $179.804^{\mathrm{a}}$ & .020 & .027 \\
\hline
\end{tabular}

Dilihat dari hasil output diatas bahwa nilai Nagelkerke $R$ Square adalah sebesar 0.027 yang berarti variabilitas variabel independen yang dapat dijelaskan oleh variabel independen adalah sebesar $2,7 \%$ sisanya $97,3 \%$ dijelaskan oleh variabel lain diluar model penelitian.

\begin{tabular}{ccccc}
\hline & Constant & KI & KA & KIN \\
\hline Step 1 Constant & 1.000 & -.269 & -.943 & .004 \\
\cline { 2 - 5 } KI & -.269 & 1.000 & .047 & -.174 \\
\cline { 2 - 5 } KA & -.943 & .047 & 1.000 & -.200 \\
\cline { 2 - 5 } & .004 & -.174 & .200 & 1.000 \\
\hline
\end{tabular}

Sumber: Output SPSS 16.0

Tabel 3 menyajikan korelasi antar variabel independen dalam penelitian ini. Matrik korelasi diatas menunjukkan tidak adanya gejala multikolinearitasyang serius antar variabel independen. Dari tabel 4.9 dijelaskan nilai korelasi antar variabel independen masih jauh dibawah 0,90 . Korelasi terendah variabel komite audit (KA) dengan variabel kepemilikan institusional (KIN) sebesar -0,200. Korelasi tertinggi terjadi antara variabel komisaris independen (KI) dengan variabel komite audit (KA) sebesar 0,047 dan sangat jauh dari 0,90.

\begin{tabular}{|c|c|c|c|c|c|c|c|c|}
\hline & & & & & & & \multicolumn{2}{|c|}{$\begin{array}{c}\text { 95,0\% C.I.for } \\
\operatorname{EXP}(B)\end{array}$} \\
\hline & & & & & & & Lower & Upper \\
\hline \multirow{4}{*}{$\begin{array}{l}\text { Step } 1^{\mathrm{a}} \text { KI KA } \\
\text { KIN } \\
\text { Constant }\end{array}$} & .001 & .012 & .009 & 1 & .923 & 1.001 & .978 & 1.025 \\
\hline & -.986 & .630 & 2.450 & 1 & .118 & .373 & .109 & 1.282 \\
\hline & .003 & .008 & .131 & 1 & .718 & 1.003 & .988 & 1.018 \\
\hline & 2.926 & 1.974 & 2.197 & 1 & .138 & 18.656 & & \\
\hline
\end{tabular}


Dari tabel 4 menunjukkan ketiga variabel bebas tidak memiliki pengaruh signifikan secara statistik dengan opini audit going concern pada nilai á atau signifikansi dibawah 5\%. Dari pengujian tersebut maka model regresi yang dapat terbentuk adalah sebagai berikut:

$$
\mathrm{OGC}=2,926+0,001 \mathrm{KI}-0.986 \mathrm{KA}+0,003 \mathrm{KIN}+\mathrm{e}
$$

Hasil penelitian ini menunjukkan bahwa komisaris independen tidak berpengaruh terhadap opini audit asumsi going concern. Hasil penelitian memberi bukti bahwa hipotesis yang diajukan $\mathrm{H} 1$ : "Komisaris independen berpengaruh terhadap penerimaan opini audit asumsi going concern" ditolak. Hasil penelitian ini mendukung dengan hasil penelitian Hartas (2011), Adi (2011) dan Adjani (2013) bahwa komisaris independen tidak berpengaruh terhadap penerimaan opini audit going concern. Namun demikian, hasil penelitian tersebut tidak sejalan dengan hasil penelitian Setiawan (2011) yang menyatakan komisaris independen berpengaruh negatif dan signifikan terhadap opini audit going concern serta hasil penelitian Ndoen (2011) bahwa komisaris independen berpengaruh positif dan signifikan terhadap opini audit going concern.

Hasil pengujian kemungkinan disebabkan karena keberadaan komisaris independen tidak menjadikan alasan pertimbangan keputusan oleh auditor independen dalam memastikan keberlanjutan atau kelangsungan hidup suatu perusahaan (going concern) dimasa depan. Bapepam mengharuskan kepada perusahaan yang terdaftar di Bursa Efek Indonesia memiliki komisaris independen minimal 30\%. Namun, keberadaan komisaris independen dalam perusahaan tidak ada perbedaan mengenai tugas dan tanggung jawab yang tergabung bersama dewan komisaris. Sehingga, tidak adanya perbedaan tanggung jawab dan tugas tersebut menyebabkan keberadaan komisaris independen tidak memberikan pengaruh terhadap kelangsungan hidup perusahaan (going concern). Selain itu, pengungkapan keberadaan komisaris independen dalam laporan tahunan menunjukkan bahwa perusahaan hanya mengikuti persyaratan yang dikeluarkan oleh bapepam bagi perusahaan yang sudah go publik, hal ini mengindikasikan bahwa implementasi sesungguhnya dalam perusahaan terkait independensi komisaris independen masih belum dirasakan pengaruhnya untuk kelangsungan dan keberlanjutan hidup perusahaan (going concern). Sebagian perusahaan memiliki komisaris independen yang masih dipertanyakan kriteria dan semangat independensinya. Hal ini didukung dengan penelitian yang dilakukan oleh Asian Development Bank (ADB) yang menerangkan penyebab krisis ekonomi di negaranegara Asia termasuk Indonesia, adalah mekanisme pengawasan dewan komisaris dan komite audit suatu perusahaan tidak berfungsi dengan efektif dalam melindungi kepentingan pemegang saham dan pengelolaan yang belum profesional (Sutedi, 2011). Berdasarkan laporan yang diungkapkan Asia Pasific Markets CLSA tahun 2004 yang menunjukkan Indonesia berada dalam posisi terbawah dibandingkan dengan negara Asia lainnya. Menurut laporan Asian Corporate Governance Association (ACGA) tahun 2012 menunjukkan posisi Indonesia pun masih berada dalam urutan terbawah dimulai dari tahun 2007 sampai tahun 2012. Hal ini dijelaskan dalam laporan tersebut bahwa penerapan good corporate governance di Indonesia masih lemah bahkan terjadi kemunduran.

Hasil penelitian ini menunjukkan bahwa komite audit tidak berpengaruh terhadap opini audit asumsi going concern. Hasil penelitian memberi bukti bahwa hipotesis yang diajukan H2: "Komite audit berpengaruh terhadap opini audit asumsi going concern" ditolak. Hasil penelitian ini mendukung hasil penelitian yang dilakukan Adi (2011) dan Setiawan (2011) bahwa komite audit tidak berpengaruh terhadap opini audit going concern.

Hasil pengujian kemungkinan disebabkan keberadaan komite audit tidak mempengaruhi kinerja auditor independen dalam mengevaluasi keberlangsungan hidup perusahaan (going concern) serta menyusun dan menerbitkan laporan dan opini auditnya. Auditor akan memberikan opini going concern berdasarkan hasil 


\section{Pengaruh Komisaris Independen...}

temuannya yang terjadi dalam perusahaan. Dengan independensinya auditor tidak dapat dikendalikan pihak manapun dalam menyusun laporan auditnya. Selain itu juga, keberadaan komite audit dalam perusahaan hanya mengikuti persyaratan bapepam yang dimana perusahaan yang go publik wajib memiliki komite audit (Adi, 2011). Komite audit dalam perusahaan hanya memberikan pandangan dalam pengawasan kinerja pelaporan keuangan serta melaksanakan pengawasan audit eksternal dan internal. Sebagian orang berpikir komite audit dalam perusahaan mengaudit layaknya akuntan publik, akan tetapi keberadaan komite audit memiliki tugas dan tanggung jawab yang lebih luas dan strategis sifatnya (Sutedi,2011).

Hasil penelitian ini menunjukkan bahwa kepemilikan institusional tidak berpengaruh terhadap opini going concern. Hasil penelitian memberikan bukti bahwa hipotesis yang diajukan H3: "Kepemilikan institusional berpengaruh terhadap penerimaan opini audit asumsi going concern, ditolak". Hal tersebut berarti hipotesis yang diajukan tidak sesuai dengan hasil penelitian. Hasil penelitian sejalan dengan Setiawan (2011) dan Adjani (2013) bahwa kepemilikan institusional tidak berpengaruh terhadap penerimaan opini audit asumsi going concern. Namun demikian, hasil penelitian ini tidak sejalan dengan hasil penelitian yang dilakukan Hartas (2011), Ndoen (2011) menyatakan bahwa kepemilikan institusional berpengaruh negatif dan signifikan terhadap penerimaan opini going concern serta hasil penelitian yang dilakukan Irfana (2012) menyatakan kepemilikan institusional berpengaruh terhadap opini audit going concern.

Hasil pengujian kemungkinan disebabkan karena secara umum prosentase kepemilikan institusional yang tinggi masih saja perusahaan menerima opini $g^{-}$ ing concern oleh auditor. Perusahaan yang menerima opini going concern dengan kepemilikan institusional yang tinggi tidak membuat auditor independen terpengaruh dalam mengevaluasi keberlanjutan usaha (going concern), menilai kemampuan perusahaan serta memberikan opini tentang perusahaan yang diauditnya. Selain itu, kepemilikan yang banyak terkonsentrasi oleh institusi akan memudahkan pengendalian sehingga akan meningkatkan kinerja perusahaan. Dalam hubungannya dengan kinerja suatu perusahaan dapat dilihat dari laporan keuangan yang sering dijadikan dasar untuk penilaian kinerja perusahaan. Salah satu jenis laporan keuangan yang mengukur keberhasilan operasi perusahaan untuk suatu periode tertentu adalah laporan laba rugi (Windah dan Fidelis, 2013). Namun, pihak institusi tidak memiliki hak untuk mengendalikan wewenang auditor independen dalam pemberian opini audit kepada perusahaan yang diragukan kelangsungan hidupnya (going concern). Auditor independen menyelesaikan pekerjaan atas dasar kondisi keuangan perusahaan saat itu juga tanpa ada pihak lain yang memanipulasi keadaan perusahaan. Auditor independen atau yang sering dikenal dengan "akuntan publik" merupakan pihak independen dari luar yang tidak tergabung atau berafiliasi (memiliki saham) dengan perusahaan, dengan demikian diharapkan pihak institusi yang memiliki prosentase kepemilikan diatas 50\% tentunya memiliki hak untuk mengendalikan perusahaan serta mengontrol tindakan yang dilakukan manajemen untuk menghindari kerugian atau pailit dan mendorong manajemen perusahaan yang ada Indonesia menerapkan prinsip-prinsip good corporate indonesia agar tidak berada diposisi terbawah yang diungkapkan dalam laporan ACGA tahun 2012.

\section{SIMPULAN}

Berdasarkan analisis dan pembahasan dalam penelitian yang menguji pengaruh komisaris independen, komite audit, kepemilikan institusional terhadap opini audit asumsi going concern pada perusahaan yang listing di Bursa Efek Indonesia tahun 2010-2012, maka diperoleh kesimpulan sebagai berikut: keberadaan komisaris independen dalam perusahaan tidak berpengaruh terhadap penerimaan 
opini audit asumsi going concern, keberadaan komite audit dalam perusahaan tidak berpengaruh terhadap penerimaan opini audit asumsi going concern, komposisi kepemilikan institusional tidak berpengaruh terhadap opini audit asumsi going concern, saham yang dimiliki oleh pihak institusi tidak mempengaruhi auditor dalam mempertimbangkan dan memberikan opini audit going concern kepada perusahaan yang mengalami tren negatif, implementasi good corporate governace di Indonesia yang terdiri dari elemen-elemen seperti komisaris independen, komite audit, kepemilikan institusional yang diharapkan dapat membantu perusahaan untuk menjaga kelangsungan hidupnya (going concern) masih lemah.

Penelitian ini memiliki beberapa keterbatasan yang memerlukan pengembangan dan perbaikan dalam penelitian selanjutnya. Adapun keterbatasan penelitian ini sebagai berikut: penelitian ini hanya fokus pada perusahaan yang mengalami kerugian operasi atau laba bersih setelah pajak negatif yang hanya menyudutkan pada salah satu faktor tren negatif opini audit going concern, pengukuran komite audit hanya berdasarkan jumlah struktur komite audit yaitu ketua ditambah anggotanya, masih belum bisa mengukur latar belakang tingkat pendidikan, pengalaman, dan jumlah frekuensi rapat.

Berdasarkan kesimpulan dan keterbatasan di atas, saran untuk penelitian selanjutnya adalah sebagai berikut: bagi penelitian selanjutnya, penelitian dapat dilakukan pada perusahaan yang mengalami laba selama periode penelitian agar dapat mengetahui perbedaan pada perusahaan yang menerima opini asumsi audit going concern oleh auditor, pengukuran komite audit dapat dilakukan dengan menggunakan frekuensi pertemuan, latar belakang, dan tingkat pendidikan.

\section{DAFTAR PUSTAKA}

Adjani,Ema Diandra. 2013. Analisis Pengaruh Corporate Governance Terhadap Kemungkinan Pemberian Opini Audit Going Concern Oleh Auditor Independen.Skripsi, Semarang: Program Sarjana (S1) pada Program Sarjana Fakultas Ekonomika dan Bisnis Universitas Diponegoro.

Adi, Jimi Uji Wijayanto. 2011. Pengaruh Dewan Direksi, Dewan Komisaris, Dan Komite Audit Terhadap Penerimaan Opini Audit Going Concern (Studi Pada Perusahaan Manufaktur Yang Terdaftar Di Bei. Skripsi. Fakultas Ekonomi, Universitas Brawijaya Malang.

Agoes, Sukrisno. 2011. Auditing Edisi 4 Buku 1. Salemba Empat. Jakarta Selatan.

Ardianingsih,Arum.2012."Analisis mekanisme corporate governance pada pemberian opini audit dengan penjelasan going concern." Jurnal Ekonomi dan Bisnis 11.01.

Arens, A. Alvin., Elder, Randal J dan Beasley, Mark S. 2008. Auditing dan Jasa Assurance. Jilid I. PT Gelora Aksara Pratama.

Chandra,Felicia Lianna.2013."Pengaruh Penerapan Good Corporate Governance Terhadap Opini Audit Mengenai Going Concern Pada Perusahaan Yang Terdaftar Dalam Bursa Efek Indonesia Periode 2010-2011." Calyptra: Jurnal Ilmiah Mahasiswa Universitas Surabaya 2.1.

Leahy.2004.Corporate Governance in Asia. Asia Editor Euromoney.

Hongkong.(Online) ${ }_{W w w . a c g a a s i a . o r g} /$ public/.../SID Article Nov04.....(Di akses 24 Januari 2015).

Dewi Prima, S. (2011). Faktor-Faktor Yang Mempengaruhi Opini Going Concern.Ejurnal:https://scholar.google.com/scholar?hl=id\&q=Dewi+2011 +Kelangsungan+hidup+suatu+entitas+\%28going+concern\%29+selalu+dih ubungkan+dengan+kemampuan+manajemen\&btnG $=$ (Diakses20November 2014). 
Pengaruh

Komisaris

Independen...

646
Hery.2013.Setiap Auditor Harus Baca Buku Ini. PT. Gramedia Widiasarana Indonesia. Jakarta.

IAPI.2013.Standar ProfesionalAkuntanPublik (SA 570).SalembaEmpat. Jakarta. Indriani,Nurkholis.2013. "Manfaat Dan Fungsi Komite Audit Dalam Mewujudkan Tata Pengelolaan Perusahaan Yang Baik (Good Corporate Governance): Persepsi Manajemen Perusahaan Go Public." Jurnal Tema 3.1: 37-58.

Linoputri, FerimaPurmateti. 2010. Pengaruh Corporate Governance TerhadapPenerimaanOpini Audit Going Concern. Skripsi, Semarang: Program Sarjana (S1) pada Program Sarjana Fakultas Ekonomika dan Bisnis Universitas Diponegoro.

Hartas,M. Haris Raedy.2011. PengaruhKualitas Audit, KondisiKeuangan, ManajemenLaba Dan Mekanisme Corporate Governance TerhadapOpini Audit Going Concern.Skripsi, Semarang: Program Sarjana (S1) pada Program Sarjana Fakultas Ekonomi Universitas Diponegoro.

Imam, Ghozali. 2011. Aplikasi Analisis Multivariat dengan Program IBM SPSS 19 Edisi 5. Badan Penerbit Universitas Diponegoro. Semarang.

Irfana, Muhammad Jauhan.2012. Analisis Pengaruh Debt Default, Kualitas Audit, Opinion Shopping Dan Kepemilikan Perusahaan Terhadap Penerimaan Opini Audit Going Concern. Diss. Fakultas Ekonomika dan Bisnis, Universitas Diponegoro Semarang.

Priyetno,Muh Agus.2014.Analisis Pengaruh Financial Distress, Leverage, Solvabilitas, Profitabilitas, Audit Delay Dan Disclosure Level Terhadap Opini Going Concern Pada Perusahaan Lq 45 Yang Terdaftar Pada Bei Tahun 20112012. Skripsi.Fakultas Ekonomi dan Bisnis, Universitas Hasanuddin Makassar.

Purba, P. Marisi. 2009. Asumsi Going Concern. Graha Ilmu. Yogyakarta.

Putranto, Akhmad Nurhadi.2014. Pengaruh Komite Audit, Kondisi Keuangan Dan Pertumbuhan Perusahaaan Terhadap Opini Audit Going Concern (Studi Empiris Pada Perusahaan Manufaktur Yang Terdaftar Di Bursa Efek Indonesia 2010-2012). Skripsi. Fakultas Ekonomi dan Bisnis Universitas Muhammadiyah Malang.

Rahmawati, Riska. 2010. Pengaruh Struktur Good Corporate Governance (GCG) Terhadap Kinerja Operasional Perusahaan LQ 45 Yang Go Public Di BEI. Skripsi. Fakultas Ekonomi Universitas Muhammadiyah Malang.

Sari, Kumala.2012.Analisis Pengaruh Audit Tenure, Reputasi Kap, Disclosure, Ukuran Perusahaan Dan Likuiditas Terhadap Penerimaan Opini Audit Going Concern (Studi Empiris pada Perusahaan Manufaktur yang Listing di BEI tahun 2005-2010). Diss. Fakultas Ekonomika dan Bisnis, Universitas Diponegoro Semarang.

Setiawan,TeguhHeri. 2011. Analisis Pengaruh Faktor Perusahaan, Kualitas Audit, Dan Mekanisme Good Corporate Governance Terhadap Penerimaan Opini Audit Going Concern. Skripsi. Fakultas Ekonomika dan Bisnis, Universitas Diponegoro Semarang. 